\title{
Effect of the addition of protected fat from palm oil to the diet of dairy sheep
}

\section{Anderson Elias Bianchi ${ }^{1,2}$, Vicente de Paulo Macedo', Aleksandro Schafer Da Silva ${ }^{3}$, André Luís Finkler da Silveira ${ }^{4^{*}}$ (iD, João Ari Gualberto Hill ${ }^{4}$, Talyta Zortéa ${ }^{5}$, Robson Marcelo Rossi ${ }^{6}$, Rafael Batista ${ }^{2}$}

\footnotetext{
${ }^{1}$ Universidade Tecnológica Federal do Paraná, Programa de Pós-graduação em Zootecnia, Dois Vizinhos, PR, Brasil.

${ }^{2}$ Universidade Federal do Paraná, Programa de Pós-graduação em Zootecnia, Curitiba, PR, Brasil.

${ }^{3}$ Universidade do Estado de Santa Catarina, Programa de Pós-graduação em Zootecnia, Chapecó, SC, Brasil.

${ }^{4}$ Instituto de Agronômico do Paraná, Pato Branco, PR, Brasil.

${ }^{5}$ Universidade Tecnológica Federal do Paraná, Programa de Pós-graduação em Agronomia, Pato Branco, PR, Brasil.

${ }^{6}$ Universidade Estadual de Maringá, Departamento de Estatística, PR, Brasil.
}

\begin{abstract}
The objective of this study was to evaluate the effect of protected fat from palm oil on body weight and milk production and composition of lactating Lacaune ewes. Four treatments $\left(0,20,40\right.$, and $60 \mathrm{~g} \mathrm{~kg}^{-1}$ as fed) of protected fat from palm oil were used to feed nine animals in each group. Isoproteic and isoenergetic diets were formulated and adjusted for each animal after milk weighing. Corn silage was used as roughage on the same proportion of concentrated to feed all animals. Milk samples were collected weekly for chemical analyses up to the seventh week of the lactation period and every other week after that until the end of the lactation period (182 days). Increased levels of protected fat in the diet of lactating ewes resulted in lower body weight gain and poor animal body condition. The production peak showed differences and was higher in the treatment of $40 \mathrm{~g} \mathrm{~kg}^{-1}$ of palm oil, but milk production during lactation was higher in animals that received $60 \mathrm{~g} \mathrm{~kg}^{-1}$ of protected fat supplementation. Animals fed $60 \mathrm{~g} \mathrm{~kg}^{-1}$ of protected fat showed the highest milk yield. We observed a positive linear effect on milk fat content, whereas the effect on milk protein, lactose, and nonfat solids was linearly negative after dairy sheep fed protected fat from palm oil. There were no changes in the amount $(\mathrm{kg})$ of milk fat, protein, lactose, total solids, and nonfat solids in any of the treatments. Therefore, protected fat from palm oil is efficient to increase milk production and fat content.
\end{abstract}

Key Words: chemical composition, dairy sheep breed, milk production

\section{Introduction}

In the South, Southeast, and Midwest regions of Brazil, there has been a significant increase in the production of dairy sheep due to several favorable factors such as fertile soil, mild climate, and topography, as well as a new niche of consumers searching for different, flavorful, and healthy foods like sheep milk and its derivatives (Bianchi et al., 2014a).

Sheep milk is primarily intended for cheese production since it may yield twice as much cheese compared with cow or goat milk (Brito et al., 2006). Therefore, sheep milk should be considered for processing into cheese and derivatives (Bencini and Pulina, 1997). During lactation, there is a high nutritional demand, and consequently, it is necessary to provide balanced diets, considering that a

Received: April 4, 2017

Accepted: December 25, 2017

*Corresponding author: andrefinkler@msn.com

Copyright (C) 2018 Sociedade Brasileira de Zootecnia. This is an Open Access article distributed under the terms of the Creative Commons Attribution License (http://creativecommons.org/licenses/by/4.0/), which permits unrestricted use, distribution, and reproduction in any medium, provided the original work is properly cited. scarce supply may lead to lower productivity and changes in milk composition (Natel, 2010). After birth, ewes with high milk production may show pronounced and long-lasting negative energy balance, which may interfere with milk production and composition, which could affect animal health (Bencini and Pulina, 1997; Ribeiro et al., 2004), forcing farmers to give diets with high energy density.

Many oils can be used as sources of fatty acids in the form of protected fat (Bona-Filho et al., 1994; Zhang et al., 2006; Sanz Sampelayo et al., 2007; Afonso et al., 2008), including palm oil. For instance, Elaeis guineensis oil contains approximately $50 \%$ of saturated and $50 \%$ of unsaturated fatty acids. Palm oil is rich in tocotrienol, a form of vitamin $\mathrm{E}$ beneficial to health in general (Bianchi et al., 2014a). The use of fat is an effective method to increase dietary energy density. On the other hand, the addition of fat may reduce fiber digestion, which can be toxic to ruminal microorganisms (Palmquist and Mattos, 2006). For this reason, the use of calcium salts of fatty acids (protected fat) may be an option since it is partially hydrogenated at normal ruminal $\mathrm{pH}$, only getting dissociated at acidic $\mathrm{pH}$ in the abomasum, thus, providing a high amount of energy into 
the bloodstream of the animal (Schauff and Clark, 1992). Therefore, the objective of the study was to evaluate the effect of diets supplemented with protected fat from palm oil on milk production and composition as well as on body weight of Lacaune sheep. In addition, we also evaluated the lactation curve of these animals since it shows the production profile.

\section{Material and Methods}

The experiment was conducted in Chapecó, Santa Catarina - Brazil $\left(27^{\circ} 02^{\prime} 10^{\prime \prime} \mathrm{S}\right.$ latitude, $52^{\circ} 39^{\prime} 27^{\prime \prime} \mathrm{W}$ longitude, and $674 \mathrm{~m}$ of altitude); the area presented average temperatures and rainfall of $19.6{ }^{\circ} \mathrm{C}$ and $942 \mathrm{~mm}$, respectively, during the experimental period (June to December 2012). In the current study, we used 36 lactating Lacaune ewes, 2-4 years of age, on their second or third lactation, with one or two offsprings. All lambs were separated from their mothers at seven days of age, when they were artificially fed. After three days of weaning, milk production and body weight were recorded, and all animals were separated into four treatments based on their body weight, age, parity order, number of lambs, and milk production. The treatments consisted of $0,20,40$, and $60 \mathrm{~g} \mathrm{~kg}^{-1}$ of protected fat from palm oil in the concentrated feed (Table 1), being the composition of the diet shown in Table 2. The amount of concentrate provided was adjusted every week, according to milk production and body weight.

The animals were restrained twice a day (07:00 and 18:00 h) in pens for individual feeding with concentrate containing protected fat, followed by corn silage (50:50). The amount of concentrate given was adjusted according to the volume of milk produced by each animal and its body weight (up to $1.4 \mathrm{~kg}$ per day), which decreased towards a

Table 1 - Composition of the experimental concentrates and diets given to sheep during lactation

\begin{tabular}{lcccc}
\hline \multirow{2}{*}{ Item } & \multicolumn{4}{c}{ Level of calcium soap $\left(\mathrm{g} \mathrm{kg}^{-1}\right.$ as fed $)$} \\
\cline { 2 - 5 } & 0 & 20 & 40 & 60 \\
\hline Ingredient & 510 & 410 & 300 & 190 \\
$\quad$ Ground corn & 430 & 430 & 410 & 400 \\
Soybean meal & 20 & 100 & 210 & 310 \\
Wheat bran & 0 & 20 & 40 & 60 \\
Calcium soap (palm oil) & 25 & 25 & 25 & 25 \\
Vitamin and mineral & 10 & 10 & 10 & 10 \\
Calcitic limestone & 5 & 5 & 5 & 5 \\
Sodium bicarbonate & & & & \\
Nutrient (g kg ${ }^{-1}$ as fed) & 887 & 890 & 892 & 895 \\
Dry matter & 215 & 219 & 218 & 219 \\
Crude protein & 22.7 & 27.3 & 28.9 & 29.4 \\
Crude fat & 734 & 739 & 737 & 738 \\
Total digestible nutrients & & & & \\
\hline
\end{tabular}

minimum of $0.6 \mathrm{~kg} / \mathrm{day}$ at the end of the experiment, when body weight was also reduced. Each animal also received $2.5 \mathrm{~kg}$ of corn silage in every meal, which was plenty since we always found leftovers that were collected and weighed.

Each treatment contained nine animals housed in pens of $24 \mathrm{~m}^{2}$. Automated milking was performed twice a day (05:00 and 17:00 h), and ten days postpartum, all milk produced was weekly individually weighed up to seven weeks using a specific equipment (True-test ${ }^{\mathbb{}}$, Auckland, New Zealand). In the subsequent weeks, milk samples were collected every other week until the end of lactation, totaling 18 weeks (182 days of lactation). Immediately after sampling, milk samples were placed into plastic bottles containing Bronopol (2-bromo-2-nitro-1, 3-propanediol) and sent under refrigeration to an official laboratory in Concórdia, Santa Catarina, Brazil.

Analyses of sheep milk composition (fat, protein, lactose, total solids, and nonfat dry extract) were performed using an infrared analyzer (Bentley $2000^{\circledR}$ ), previously used to test bovine milk. The reliability of the equipament to test sheep milk was checked and confirmed, i.e., the correlation between the results from this equipment and conventional methods was higher than $90 \%$ for all the parameters studied, without any significant differences between both methods ( $P>0.05)$ (Penna, 2011).

All animals were weighed using an electronic scale, their body condition was scored, and the volume of milk produced was registered. The methodology to evaluate body condition score (BCS) was previously described by Cañeque et al. (1989), assigning values of 1 to 5 with 0.25 increase, in which 1 was for extremely thin and 5 for obese ewes.

To compose the lactation curve, each day of the lactation period (182) was considered one observation. Data from milk production were fitted on a nonlinear regression, and production peak, day of peak production, and lactation persistency (in months) were considered variables of the curve, by means of the proposed model of Wood (1963) with the following equation 1 :

$Y_{i j k}=a_{k} t_{i j k}^{b_{k}} e^{-c_{k} t_{j i k}}$

Equation (1) in which, $i$ is the animal $(1,2, \ldots, \mathrm{N}) ; j$ is the time: $1,2, \ldots, \mathrm{J}$; $k$ is the treatment $(1,2, \ldots, \mathrm{K}) ; \mathrm{y}$ is the milk production (L/day); $a$ is the initial production of milk $(\mathrm{L}) ; b$ is the rate of increase of production to peak; $c$ is the rate of production decline after peak (persistency factor); $t$ is the day of lactation.

To estimate the production peak $(p p)$, day of peak production (dpp), and persistency $(s)$ in months, we used the parameters of Wood's curve (equation 2, 3 and 4). For the Bayesian model, it was considered that the observations followed a normal distribution, i.e., 
Table 2 - Chemical composition of feed used in the experimental diets for lactating ewes

\begin{tabular}{|c|c|c|c|c|c|}
\hline Ingredient ( $\mathrm{g} \mathrm{kg}^{-1}$ as fed) & Corn silage & Corn ground & Soybean meal & Wheat bran & $\begin{array}{l}\text { Calcium soap } \\
\text { (palm oil) }\end{array}$ \\
\hline Dry matter & 313.8 & 887.2 & 895.2 & 896.3 & 972.6 \\
\hline Crude protein & 73.6 & 91.2 & 445.6 & 154.7 & - \\
\hline Crude fat & 35.6 & 36.1 & 16.6 & 24.6 & 848.7 \\
\hline Neutral detergent fiber & 498.5 & 89.0 & 138.0 & 365.2 & - \\
\hline Acid detergent fiber & 237.1 & 28.9 & 81.6 & 138.5 & - \\
\hline
\end{tabular}

$y_{\mathrm{i}} \sim N\left(f\left(t_{\mathrm{i}}\right), \tau\right)$ being $f\left(t_{\mathrm{i}}\right)$ in (1) and standard deviation $\sigma=\tau^{-1 / 2}$ (parameterization OpenBugs). We considered the prior noninformative distributions for all model parameters given in (1), considering the investigated treatments: $a \sim \operatorname{Gamma}\left(10^{-2}, 10^{-2}\right) ; b \sim \operatorname{Unifom}(0,1) ; c \sim \operatorname{Unifom}(0,1)$; and $\tau \sim \operatorname{Gamma}\left(10^{-3}, 10^{-3}\right)$.

$p p=a\left(\frac{b}{c}\right)^{b} e^{-b}, d p p=\frac{b}{c}$ and $s=-(b+1) \ln (c)$

Equations (2, 3, and 4, respectively)

Multiple comparisons between posterior distributions from the averages of the parameters of interest were made to compare treatments. Significance was considered at $5 \%$ level for treatments that showed credibility intervals for mean differences that did not include zero, obtaining marginal posterior distributions for all parameters through Brugs package of the program R ( $\mathrm{R}$ Development Core Team, 2014). It generated $1,100,000$ values in a Markov Chain Monte Carlo process, considering a sampling discart of 100,000 initial values; thus, the final sample obtained every 100 jumps contained 10,000 values. The convergence of the chains was verified by the CODA package of the program R, according to the criterion of Heidelberger and Welch (1983).

This study had a randomized experimental design with four treatments and nine replicates, considering each animal as one repetition. Data from animal performance, milk composition, and production were subjected to analysis of variance using SAS software (Statistical Analysis System, version 8.1 ) at a significance level of $5 \%$ according to the statistical model (Equation 5). Initialy, we searched for interactions between treatment and lactating period for all variables. As a result, we found that fat content was the only variable with this type of interaction, and it was analysed for all milking periods (initial, intermediate, and final). Since the other variables did not show interaction, they were evaluated as one single milking period.

$Y_{i j}=\mu+T_{i}+\varepsilon_{i j}$,

Equation (5)

in which, $Y_{i j}$ is the response variable in the $j$; $\mu$ is the overall average; $T_{i}$ is the fixed effect of the $i$ treatment; and $\varepsilon_{i j}$ is the random error. It is assumed that $\varepsilon_{i j} \sim \operatorname{NID}\left(0, \sigma^{2}\right)$.
When the factors were significant, they underwent a polynomial regression testing. However, when the regression was not significant, multiple comparisons of means were performed by Tukey test at $5 \%$ probability $(\mathrm{P}<0.05)$, using the MIXED procedure of SAS with the model in Equation 6.

$Y_{i j}=\mu+T_{i}+W_{j}+T \times W_{i j}+\varepsilon$,

Equation (6) in which $Y_{i j}$ is the observation $i j ; \mu$ is the general average; $T_{i}$ is the effect of treatment $i ; W$ is the effect of lactation week $j$; $T \times W$ is the effect of the interaction between treatment $i$ and week $j$; and $\varepsilon$ is the random error. The week factor was considered a repeated measure in the model.

\section{Results}

The addition of protected fat showed effect $(\mathrm{P}<0.0001)$ on sheep body weight (Table 3), i.e., animals that received $20 \mathrm{~g} \mathrm{~kg}^{-1}$ protected fat were heavier. It was also noted that the average daily intake of dry matter was $2.24 \mathrm{~kg}$ per animal, representing $34.8 \mathrm{~g} \mathrm{~kg}^{-1}$ day $^{-1}$ of the body weight. There were differences in body condition score $(\mathrm{P}<0.05)$, similarly to body weight.

Initially, all four treatments showed similar milk production $(a)$ (1.85 kg of milk) (Table 4). There was no significant increase in the production peak $(b)$, even though there was a slight tendency to be higher in animals fed 40 and $60 \mathrm{~g} \mathrm{~kg}^{-1}$ protected fat. There was no statistical difference regarding the day of peak production ( $(p p)$ with an average of 17 days of experiment, but the study began when the animals were at 10 days of lactation (postpartum), so the real production peak was reached at 27 days, i.e., in the fourth week of lactation (Table 4). The rate of decline in milk production after peak $(c)$ was similar for both groups $(\mathrm{P}<0.005)$. The production peak $(p p)$ showed differences and was higher in the treatment of $40 \mathrm{~g} \mathrm{~kg}^{-1}$ palm oil. Based on these parameters, lactation curve was composed (Figure 1). We emphasize that milk production during lactation was higher in animals that received $60 \mathrm{~g} \mathrm{~kg}^{-1}$ as fed of protected fat supplementation (Figure 2). 
Table 3 - Body weight (kg), body condition score (BCS), and dry matter intake of sheep fed different levels of protected fat

\begin{tabular}{|c|c|c|c|c|c|}
\hline \multirow{2}{*}{ Variable } & \multicolumn{4}{|c|}{ Level of protected fat concentrate $\left(\mathrm{g} \mathrm{kg}^{-1}\right.$ as fed) } & \multirow{2}{*}{ Mear } \\
\hline & 0 & 20 & 40 & 60 & \\
\hline Initial body weight (kg) & 57.91 & 56.60 & 55.28 & 55.05 & 56.21 \\
\hline Mean body weight (kg) & $67.77 \pm 0.75 \mathrm{a}$ & $66.70 \pm 0.74 \mathrm{a}$ & $63.58 \pm 0.74 \mathrm{~b}$ & $62.64 \pm 0.74 b$ & 65.17 \\
\hline Final body weight (kg) & 76.51 & 74.44 & 68.78 & 69.28 & 72.25 \\
\hline Initial BCS & 1.56 & 1.72 & 1.78 & 1.61 & 1.67 \\
\hline Mean BCS & $2.78 \pm 0.03 \mathrm{a}$ & $2.77 \pm 0.03 \mathrm{a}$ & $2.81 \pm 0.03 \mathrm{a}$ & $2.67 \pm 0.03 b$ & 2.75 \\
\hline $\mathrm{kg} / \mathrm{animal} /$ day & 2.24 & 2.25 & 2.12 & 2.32 & 2.24 \\
\hline Body weight $\left(\mathrm{g} \mathrm{kg}^{-1} \mathrm{~d}^{-1}\right)$ & 33.50 & 34.20 & 33.80 & 37.40 & 34.80 \\
\hline
\end{tabular}

a,b - Means followed by different letters in the same line differ by Tukey test $(\mathrm{P}<0.05)$.

Table 4 - Bayesian estimates (mean \pm standard deviation) for parameters of the lactation curve

\begin{tabular}{|c|c|c|c|c|c|c|}
\hline \multirow{2}{*}{$\begin{array}{l}\text { Protected fat } \\
\left(\mathrm{g} \mathrm{kg}^{-1} \text { as fed }\right)\end{array}$} & \multicolumn{6}{|c|}{ Parameter/Bayesian estimate } \\
\hline & $a$ & $b$ & $c$ & $p p$ & $d p p$ & $s$ \\
\hline 0 & $1.85 \pm 0.16 \mathrm{a}$ & $0.08 \pm 0.033 \mathrm{a}$ & $0.005 \pm 0.0008 \mathrm{a}$ & $2.13 \pm 0.07 \mathrm{ab}$ & $16 \pm 5 \mathrm{a}$ & $5.76 \pm 0.11 \mathrm{a}$ \\
\hline 20 & $1.83 \pm 0.13 \mathrm{a}$ & $0.07 \pm 0.026 \mathrm{a}$ & $0.005 \pm 0.0006 \mathrm{a}$ & $2.09 \pm 0.05 \mathrm{~b}$ & $16 \pm 4 \mathrm{a}$ & $5.82 \pm 0.09 \mathrm{a}$ \\
\hline 40 & $1.88 \pm 0.13 \mathrm{a}$ & $0.09 \pm 0.025 \mathrm{a}$ & $0.005 \pm 0.0006 \mathrm{a}$ & $2.25 \pm 0.05 \mathrm{a}$ & $18 \pm 3 a$ & $5.78 \pm 0.08 \mathrm{a}$ \\
\hline 60 & $1.86 \pm 0.14 \mathrm{a}$ & $0.10 \pm 0.029 \mathrm{a}$ & $0.005 \pm 0.0007 \mathrm{a}$ & $2.24 \pm 0.06 \mathrm{ab}$ & $19 \pm 4 \mathrm{a}$ & $5.81 \pm 0.09 \mathrm{a}$ \\
\hline
\end{tabular}

$a$ - initial production of milk (L); $b$ - rate of production increase up to the peak; $c$ - rate of production that declined after peak (persistency factor); $p p$ - production peak (L); $d p p$ - day of peak production; s - persistency in months.

a,b - Different letters in the same column indicate significant differences between the mean of treatments by comparing Bayesian with $95 \%$ credibility.

The fat content in the milk from sheep fed different levels of palm oil showed an interaction between treatment and period $(\mathrm{P}<0.01)$. In the initial third, which comprises the early lactation (1 to 60 days), there was a linear effect $(\mathrm{P}<0.01)$, that is, increased level of protected fat caused an increase in fat content (Figure 2). In the second stage, in the intermediate third of the lactating period (61 to 120 days), the fat content had a quadratic effect $(\mathrm{P}<0.05)$, with decreased fat content in treatments with 20 and $40 \mathrm{~g} \mathrm{~kg}^{-1}$ palm oil (Figure 2). In the final third of the lactation period (121 to 182 days), the fat content showed a linear effect $(\mathrm{P}<0.05)$, similarly to early lactation, i.e., animals that received higher levels of palm oil showed higher milk fat content (Figure 2). Milk fat content throughout lactation (182 days) also showed a linear effect $(\mathrm{P}<0.05)$.

The addition of protected fat showed a linear effect $(\mathrm{P}<0.01)$ on protein content, demonstrating a negative correlation (decreased protein content when increased levels of palm oil was used) (Figure 3). Lactose content also showed a linear effect $(\mathrm{P}<0.01)$, indicating that higher levels of fat lead to decreased levels of lactose (Figure 3). Similarly, defatted dry extract content (Figure 3) showed a linear profile $(\mathrm{P}<0.001)$, e.g., increased levels of palm oil, decreased levels of defatted dry extract content. The percentage of total solids in milk had no significant effect ( $P>0.05$ ), with a mean of $167.6 \mathrm{~g} \mathrm{~kg}^{-1}$. No significant effect $(P>0.05)$ on total yield of solids (Table 5) was observed.

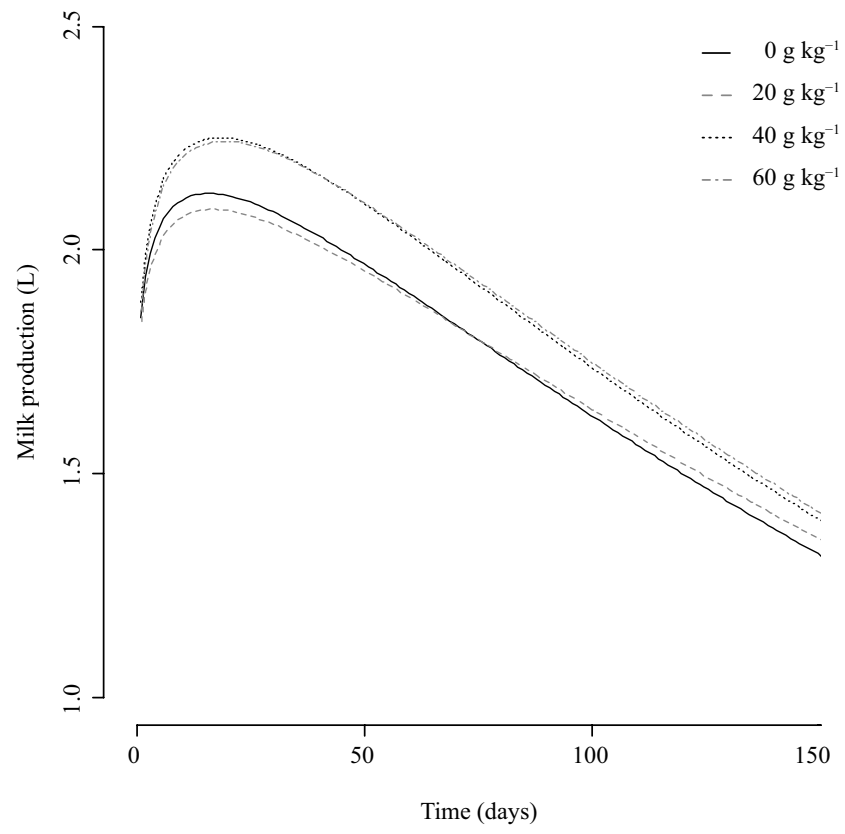

Figure 1 - Lactation curve adjusted for different levels of protected fat $\left(0,20,40\right.$, and $\left.60 \mathrm{~g} \mathrm{~kg}^{-1}\right)$.

\section{Discussion}

Animals that received the highest levels of protected fat (40 and $\left.60 \mathrm{~g} \mathrm{~kg}^{-1}\right)$ had lower body weight and the worst BCS throughout the lactation period, possibly because these animals had greater milk production throughout lactation. Therefore, weight loss during the first four weeks 

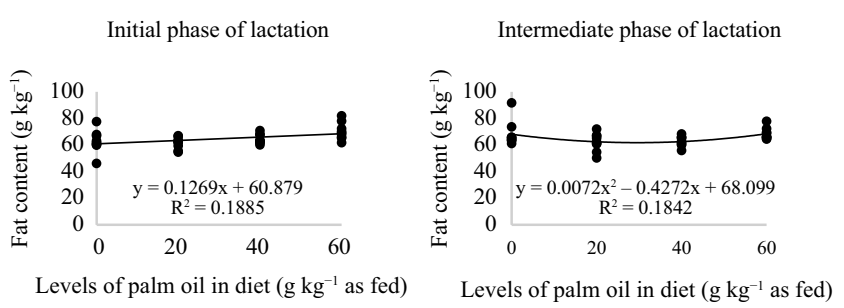

Final phase of lactation
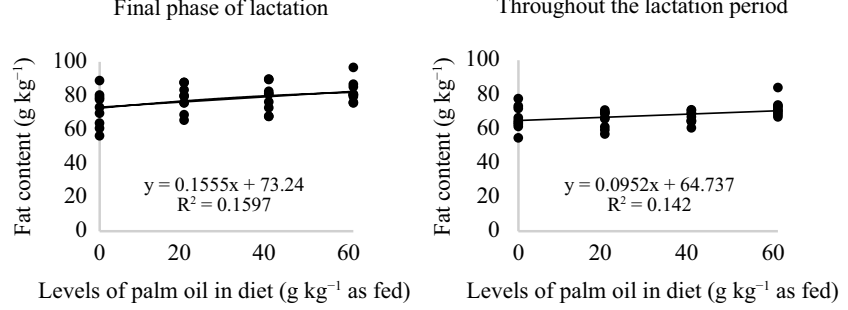

Figure 2 - Levels of fat in the milk of sheep fed different levels of protected fat in the initial, intermediate, and final phases and throughout the lactation period of 182 days.

of lactation is usually minimal, but it may be more severe with the lactation persistency (Snowder and Glimp, 1991). In our study, there was no body weight loss, only a lower body weight gain in those animals that produced more milk and received higher amounts of protected fat.

Another contributing factor to lower body weight in sheep fed higher levels of protected fat might be related to the fact that their milk has higher amounts of fat; thus, these animals demanded larger quantities of nutrients to synthesize fatter milk to use less tissue deposition. According to the literature, increased amount of milk production and milk fat content might be possible due to sheep weight loss (Barnes et al., 1990). Another study using $0,30,60$, and $90 \mathrm{~g} \mathrm{~kg}^{-1}$ protected fat for goats showed a decrease in weight gain (110.3, 67.5, 53.3, and $39.6 \mathrm{~g}$, respectively) (Teh et al., 1994), similarly to those found in this study.

The lactation curve showed a difference in milk production at the lactation peak, that is, sheep that received higher amounts of palm oil showed higher peaks, resulting in greater milk production throughout lactation since the rate of decline after the peak was the same for all treatments. In this study, the lactation peak occurred approximately at day 27 postpartum, a fact also shown by Bencine and Pulina (1997), in which the lactation peak was reached between the third and the fifth week of lactation. Another study showed that milk production peak in confined sheep with a suckling lamb occurred after 30 days of lactation; however, females with twins showed lactation peak at 21 days of lactation (Cardellino and Benson, 2002). Mixed system of sheep milk production (lamb suckling + milking until 45 days of age) showed production peak in the seventh week of lactation (Stradioto, 2007). In this case, according to the
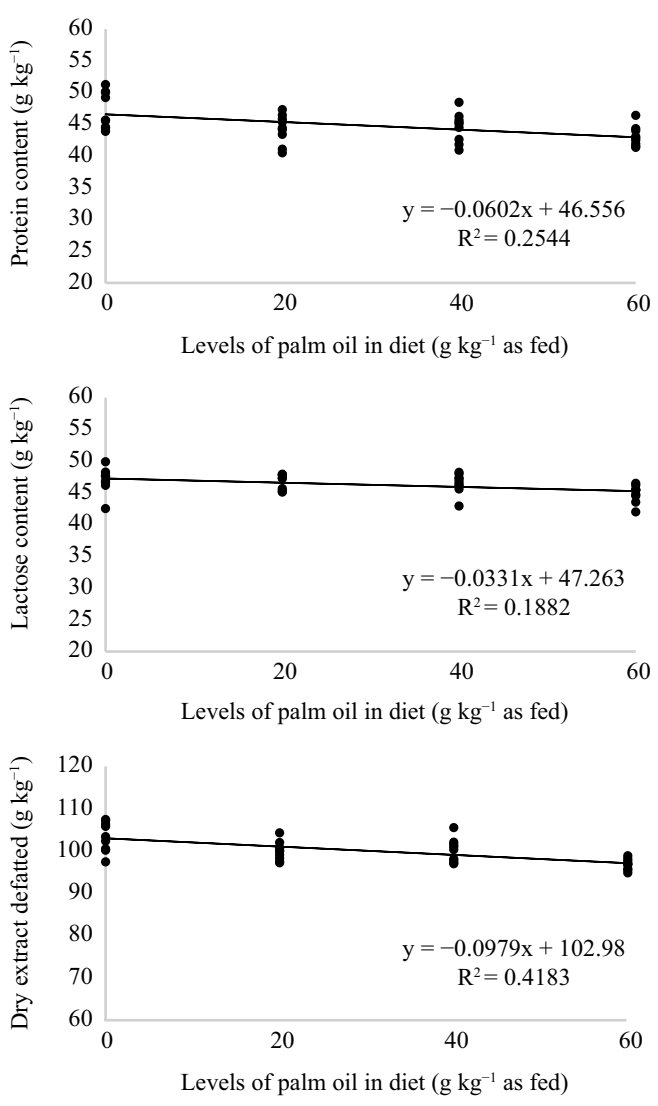

No different total dry extract was observed.

Figure 3 - Protein, lactose, and defatted dry extract content of milk from sheep fed different levels of protected fat during lactation.

authors, the peak may have been slowed by the effect of lamb suckling, which may have hampered milk production.

The mean and total volume of milk produced throughout the lactation period was greater in animals that received higher amounts of protected fat (40 and $60 \mathrm{~g} \mathrm{~kg}^{-1}$ ). The fat content in milk throughout lactation increased linearly with higher amounts of palm oil. Fontaneli (2001) reported that milk fat is composed almost entirely by triglycerides ( $98 \%$ of total fat). These triglycerides are synthesized in the epithelial cells of the mammary gland, and fatty acids composing these triglycerides may be derived from lipids present in the blood or by the de novo synthesis in the epithelial cells. Thus, there is a great uptake of triglycerides from the bloodstream by the mammary gland, which is used for the synthesis of fat that will be milk secreted. It is worth highlighting that sheep that received palm oil in the $\operatorname{diet}\left(40\right.$ and $\left.60 \mathrm{~g} \mathrm{~kg}^{-1}\right)$ had an increase in seric triglycerides (Bianchi et al., 2014b), which may explain the numerical increase in milk fat of sheep that received $60 \mathrm{~g} \mathrm{~kg}^{-1}$ palm oil in the diet. Cannas et al. (2002) reported that the use of protected fat for sheep caused an increase in milk production and fat content. However, these findings occur much faster for fat content than for milk production. 
Table 5 - Total production of fat, protein, lactose, total dry extract, and defatted dry extract in milk of Lacaune sheep fed different levels of protected fat during the lactation period (182 days)

\begin{tabular}{|c|c|c|c|c|c|c|c|}
\hline \multirow{2}{*}{ Variable $(\mathrm{kg})$} & \multicolumn{4}{|c|}{ Level of protected fat concentrate $\left(\mathrm{g} \mathrm{kg}^{-1}\right.$ as fed) } & \multirow{2}{*}{ Mean } & \multirow{2}{*}{$\mathrm{CV}(\%)$} & \multirow{2}{*}{ Effect } \\
\hline & 0 & 20 & 40 & 60 & & & \\
\hline$\overline{\text { Fat }}$ & 21.23 & 20.93 & 22.76 & 24.42 & 22.33 & 19.01 & ns \\
\hline Protein & 15.23 & 14.32 & 15.35 & 14.58 & 14.87 & 19.34 & ns \\
\hline Lactose & 15.70 & 15.38 & 16.39 & 15.59 & 15.76 & 20.75 & ns \\
\hline Total dry extract & 55.31 & 53.63 & 57.85 & 57.54 & 56.08 & 19.32 & ns \\
\hline Defatted dry extract & 33.98 & 32.69 & 34.94 & 33.24 & 33.71 & 19.84 & $\mathrm{~ns}$ \\
\hline
\end{tabular}

$\mathrm{CV}$ - coefficient of variation; ns - no significant effect $(\mathrm{P}>0.05)$.

Filgueiras Neto and Moura (2012) reported that high-producing dairy cows may have severe ruminal $\mathrm{pH}$ decrease, even when well fed with balanced diets. This is more commonly seen when protected fat from soybean is used, compared with protected fat from palm oil. The reason for that relies, in part, on the amount of polyunsaturated fatty acids that is much lower in palm oil than in soybean, and its $\mathrm{pKa}$ is also lower even when the ruminal $\mathrm{pH}$ is bellow normal, allowing the release of fatty acids in the rumen with low dissociation, and without any effect on ruminal microorganisms. Therefore, there is no severe impact on the biohydrogenation of fats in the rumen and, consequently, on milk fat content. Due to these factors, it is possible to assure that protected fat from palm oil is safer since it ensures similar energy input compared with fat from soybean oil and decreases the risk of lower levels of fat in milk (Filgueiras Neto and Moura, 2012).

The protein content in milk showed a linear decrease after an increase in the levels of palm oil. This fact may be due to a dilution factor since the total volume of milk also increased, and consequently, the total protein production during lactation ( $\mathrm{kg}$ protein) showed no significant difference, demonstrating that the use of higher levels of protected fat to feed lactating ewes did not affect the total amount of protein secreted in milk. According to the literature, there is a negative correlation between milk production and milk composition. Therefore, when sheep produced more milk volume, the fat and protein concentrations were reduced, and this is also valid for breed of high and low production (Bencine and Pulina, 1997).

According to Chilliard et al. (2003), milk protein production is related to nutritional factors, energy intake being the major factor. We did not anticipate changes in the levels of protein, given that the diets were formulated to meet animal production needs. Replacing the sources of fermentable carbohydrates in the rumen with unsaturated fat leads to lower production of volatile fatty acids and, overall, to a lower production of microbial protein. The reduced production of these fatty acids in the rumen leads to greater gluconeogenesis from amino acids by decreasing the concentration of protein in milk (Wu and Huber, 1994). In the present study, we observed a decrease in protein levels of milk from animals that received higher amounts of protected fat. There are two possible explanations for that: increased milk production leads to lower protein levels, and a dilution event may have ocurred (Table 5), with no changes on protein $(\mathrm{kg})$; the second explanation was mentioned above, with a $\mathrm{pH}$ drop with dissociation of protected fat, and release of unsaturated fat.

This effect was evidenced by Fernandes et al. (2008), who reported that the use of certain types of additional fat increased milk production, as well as the percentage of fat in milk, but at the same time, also decreased the percentage of protein. When there is no replacement of carbohydrates for lipids in the rumen, and when lipids are supplied in very large amounts, there is a toxic effect on microorganisms of the rumen, causing reduction in microbial growth and, thus, an effect on the transport of amino acids to the mammary gland. Therefore, the protein content of milk may decrease with the deficiency of one or more amino acids (Santos et al., 2001).

Lactose content in milk from sheep decreased as they were fed higher amounts of protected fat. This might be explained by the dilution of this compound as a consequence of a higher milk production. Fontaneli (2001) reported that glucose is the major precursor of lactose in milk and contributes with approximately 60 to $70 \%$ for the synthesis of this component; the rest of the glucose is used by the secretory cells for protein synthesis, and glycerol or other precursors, for the synthesis of fat. Authors reported that the main precursor of animal glucose is propionic acid, mainly produced by the fermentation of non-fibrous carbohydrates in the rumen (Antunes and Rodriguez, 2006). Thus, the inclusion of protected fat has little effect on propionate production, not interfering with the synthesis of glucose by the liver, and subsequently lactose by the mammary gland. As observed in our study using isocaloric diets, the way to increase the levels of protected fat was to 
decrease ground corn, a source of non-fiber carbohydrate, thus reducing the production of propionic acid, a precursor of glucose, thereby reducing lactose in milk. This study also found that the treatments caused a linear effect $(\mathrm{P}<0.0001)$ on solids nonfat. This decrease in dry fat extract in relation to increased levels of palm oil is because it is mainly composed of protein and lactose, demonstrating similar patterns between compounds.

The total solid content (fat, protein, lactose, and minerals) in milk showed no significant differences between groups since fat content is inversely proportional to the levels of protein and lactose, which was found in milk of all groups. Likewise, total production of solids did not change among groups, and a possible reason for this is that the values were calculated by multiplying milk production and solids. The amount $(\mathrm{kg})$ of protein, lactose, and solids nonfat showed no significant changes since their concentration were inversely proportional to milk production. We expected that the total production of fat would show a significant increase because fat content showed a positive linear effect, and milk production followed the same trend, but this fact did not occur, probably due to the high coefficient of variation (19.01\%) found for this variable.

\section{Conclusions}

The addition of low amounts $\left(20 \mathrm{~g} \mathrm{~kg}^{-1}\right)$ of protected fat from palm oil in the diet of dairy sheep causes a positive effect on weight gain and body condition. Moreover, milk production and fat content are higher in sheep that receive $60 \mathrm{~g} \mathrm{~kg}^{-1}$ of protected fat. On the other hand, protein, lactose, and solids nonfat are lower in milk of ewes fed protected fat.

\section{Acknowledgments}

We thank the Cabanha Chapecó farm, for providing the animals used in the research.

\section{References}

Afonso, V. A. C.; Quirino, C. R. and Bueno, M. S. 2008. Intervalo de partos em ovelhas da raça Santa Inês suplementadas com ácidos graxos. Veterinaria \& Zootecnia 15:129.

Antunes, R. C. and Rodriguez, N. M. 2006. Metabolismo dos carboidratos não estruturais. p.583-630. In: Nutrição de ruminantes. Berchielli, T. T.; Pires, A. V. and Oliveira, S. G., eds. Funep, Jaboticabal.

Barnes, M. A.; Pearson, R. E. and Lukes-Wilson, A. J. 1990. Effects of milking frequency and selection for milk yield on productive efficiency of Holstein cows. Journal of Dairy Science 73:1603-1611. https://doi.org/10.3168/jds.S0022-0302(90)78831-5

Bencini, R. and Pulina, G. 1997. The quality of sheep milk: A review. Australian Journal of Experimental Agriculture 37:485-504.

Bianchi, A. E.; Macedo, V. P.; Duarte, M. M. F.; Lopes, L. S.; Stefani, L. M.; Rossett, J.; Klauck, V.; Radavelli, W.; Pazinato, R.; Bottari, N. B. and Da Silva, A. S. 2014a. The effect of palm oil addition to the diet of dairy sheep on the immune response. Journal Animal Physiology and Animal Nutrition 98:446-452. https://doi.org/10.1111/jpn.12091

Bianchi, A. E.; Macedo, V. P.; França, R. T.; Lopes, S. T. A.; Lopes, L. S.; Stefani, L. M.; Volpato, A.; Lima, H. L.; Paiano, D.; Machado, G. and Da Silva, A. S. 2014b. Effect of adding palm oil to the diet of dairy sheep on milk production and composition, function of liver and kidney, and the concentration of cholesterol, triglycerides and progesterone in blood serum. Small Ruminant Research 117:78-83. https://doi.org/10.1016/j.smallrumres.2013.12.025

Bona-Filho, A.; Otto, C.; Brondani, L. F.; Sá, J. L.; Yada, R. S. and Sotomaior, C. S. 1994. Efeitos da utilização de diferentes níveis de sais cálcicos de ácidos graxos no desempenho de ovelhas no pós-parto. Revista de Ciências Agrarias 13:111-117.

Brito, M. A.; González, F. D.; Ribeiro, L. A.; Campos, R.; Lacerda, L.; Barbosa, P. R. and Bergmann, G. 2006. Composição do sangue e do leite em ovinos leiteiros do sul do Brasil: Variações na gestação e lactação. Ciência Rural 36:942-948.

Cañeque, V.; Huildobro, F. R. and Dolz, J. F. 1989. Producción de carne de cordero. Colección Técnica, Madrid.

Cannas, A.; Nudda, A. and Pulina, G. 2002. Nutritional strategies in improve lactation persistency in dairy ewes. p.17-59. In: Proceedings of the 8th Great Lakes Dairy Sheep Symposium. Wisconsin Sheep Cooperative Dairy, Ithaca.

Cardellino, R. A. and Benson, M. E. 2002. Lactation curves of commercial ewes rearing lambs. Journal of Animal Science 80:23-27. https://doi.org/10.2527/2002.80123x

Chilliard, Y.; Ferlay, A.; Rouel, J. and Lamberet G. 2003. A review of nutritional and physiological factors affecting goat milk lipid synthesis and lipolysis. Journal of Dairy Science 86:1751-1770. https://doi.org/10.3168/jds.S0022-0302(03)73761-8

Fernandes, M. F.; Queiroga, R. C. R. E.; Medeiros, A. N.; Costa, R. G.; Bonfim, M. A. D. and Braga, A. A. 2008. Características físico-químicas e perfil lipídico do leite de cabras mestiças Moxotó alimentadas com dietas suplementadas com óleo de semente de algodão ou de girassol. Revista Brasileira Zootecnia 37:703-710. https://doi.org/10.1590/S1516-35982008000400017

Filgueiras Neto, G. and Moura, M. T. 2012. Gordura protegida: 30 anos no mercado sempre com as mesmas dúvidas. Available at: $<$ www.holandesparana.com.br/artigos/ArtigoGPNT032012.pdf $>$. Accessed on: Dec. 14, 2013.

Fontaneli, R. S. 2001. Fatores que afetam a composição química $\mathrm{e}$ as características físico-químicas do leite. Available at: $<$ http://people.ufpr.br/ freitasjaf/artigos/composicaoleite.pdf $>$. Accessed on: Oct. 26, 2013.

Heidelberger, P. and Welch, P. D. 1983. Simulation run length control in the presence of an initial transient. Operations Research 31:1109-1144. https://doi.org/10.1287/opre.31.6.1109

Natel, A. S. 2010. Produção, composição do leite e comportamento de ovelhas da raça Bergamácia sob dietas com níveis crescentres de FDN. Dissertação (M.Sc.). Universidade Estadual Paulista, Botucatu.

Palmquist, D. and Mattos, W. 2006. Metabolismo de lipídeos. p.151-182. In: Nutrição de ruminantes. Berchielli, T. T.; Pires, A. V. and Oliveira, S. G., eds. Funep, Jaboticabal.

Penna, C. F. A. M. 2011. Produção e parâmetros de qualidade de leite e queijos de ovelhas Lacaune Santa Inês e suas mestiças submetidas 
a dietas elaboradas com soja e linhaça. Tese (D.Sc.). Universidade Federal de Minas Gerais, Belo Horizonte.

Ribeiro, L. A. O.; Mattos, R. C.; Gonzalez, F. H. D.; Wald, V. B.; Silva, M. A. and La Rosa, V. L. 2004. Perfil metabólico de ovelhas Border Leicester x Texel durante a gestação e a lactação. Revista Portuguesa de Ciências Veterinarias 99:155-159.

Santos, F. L.; Lana, R. P.; Silva, M. T. C.; Brandão, S. C. C. and Vargas, L. H. 2001. Produção e composição do leite de vacas submetidas a dietas contendo diferentes níveis e formas de suplementação de lipídios Revista Brasileira de Zootecnia 30:1376-1380. https://doi.org/10.1590/S1516-35982001000500034

Sanz Sampelayo, M. R.; Chilliard, Y.; Schmidely, P. and Boza, J. 2007. Influence of type of diet on the fat constituents of goat and sheep milk. Small Ruminant Research 68:42-63. https://doi.org/10.1016/j.smallrumres.2006.09.017

Schauff, D. J. and Clark, J. H. 1992. Effects of feeding diets containing calcium salts of long-chain fatty acids to lactating dairy cows. Journal of Dairy Science 75:2990-3002. https://doi.org/10.3168/jds.S0022-0302(92)78063-1

Snowder, G. D. and Glimp, H. A. 1991. Influence of breed, number of suckling lambs, and stage of lactation on ewe milk production and lamb growth under range conditions. Journal of Animal Science 69:923-930. https://doi.org/10.2527/1991.693923x

Stradioto, M. M. 2007. Efeito da gordura protegida sobre a composição do leite, anestro pós-parto, resposta as infecções parasitárias e desempenho de cordeiros, em ovelhas da raça Bergamácia. Dissertação (M.Sc.). Universidade Estadual Paulista, Botucatu.

Teh, T. H.; Trung, L. T.; Jia, Z. H.; Gipson, T. A.; Ogden, K. B. and Sweenwy, T. F. 1994. Varying amounts of rumen-inert fat for high producing goats in early lactation. Journal of Dairy Science 77:253-258. https://doi.org/10.3168/jds.S0022-0302(94)76948-4

Wood, P. D. P. 1963. Algebraic of the lactation curve in cattle. Nature 216:164-165.

Wu, Z. and Huber, J. T. 1994. Relationship between dietary fat supplementation and milk protein concentration in lactating cows: a review. Livestock Production Science 39:141-155. https://doi.org/10.1016/0301-6226(94)90180-5

Zhang, R.; Mustafa, A. F. and Zhao, X. 2006. Effects of flaxseed supplementation to lactating ewes on milk composition, cheese yield, and fatty acid composition of milk and cheese. Small Ruminant Research 63:233-241. https://doi.org/10.1016/j.smallrumres.2005.02.024 